\title{
Global Smart Grid Transferability: Insights from Europe, the U.S., and China
}

\author{
Zheng Ma, Bo Nørregaard Jørgensen and Zerina Prljaca \\ Center for Energy Informatics, University of Southern Denmark, Odense 5230, Denmark
}

Received: September 15, 2015 / Accepted: October 09, 2015 / Published: December 31, 2015.

\begin{abstract}
The paper tries to address the question of whether the smart grid solution can be transferred internationally, and explore the transferability of the smart grid across countries with three national comparisons: USA, Europe and China. A qualitative content analysis in which data (the academic papers) are coded in preparation for comparison and interpretation is chosen to find the similarities and differences of smart grid development in different national contexts. Trough a comparative analysis of the smart grid development in USA, Europe and China, this paper conducts a transferable framework of smart grid solution with global and local features.
\end{abstract}

Key words: Smart grid, globalisation, comparison, Europe, the U.S., China.

\section{Introduction}

Smart grid is an upcoming technology being applied currently in developed countries, e.g., US, EU, Japan [1]. Many other countries, such as China, Africa and Thailand, are all aware the important and start to develop this area, e.g., Sebitosi and Okou [2]. According to Hashmi, Hanninen and Maki [3], "the definition of smart grid can also depend on local conditions, different countries can have very different starting points for the process towards smart grid". Smart grids development appears to differ in many interesting ways when compared with other countries [4]. The main challenge of the global smart grid solution can be argued as readiness of utilities, ICT (information and communication technology) and consumer management. For instance, smart grid technologies are mainly deployed with regional, country, or utility specific objectives and requirements, to be quantified in the areas of environmental goals, security of electricity supply, and macro-economic growth and business sustainability development [5].

However, this paper argues that, the global drivers

Corresponding author: Zheng Ma, associate professor, research field: management enginnering of smart energy. and challenges provide a possible platform for the international transition of the smart grid solution, such cross-national technological and managerial transfer. The global smart grid market has huge potential due to the enormous market need. However, the global smart grid solution is more complex compared to the existing smart grid solution, which not only interrelates utility readiness and variable factors' embeddedness, but also tailor their strategies for specific national market needs. Despite the recognition of the importance of the smart grid globalization, there has been little research to provide the smart grid solution in the dynamic market.

Plenty of researches have done the comparative studies of the smart grid development with the national or cross-national aspects, e.g., Refs. [6-9]. Majority of the research focuses on the technological aspects, and little has stated the correlation across countries or the management aspects. In order to fill the gap, this paper seeks to examine the question of whether the smart grid solution can be transited internationally, and what are the impact factors. In addressing this question, our specific focus is on the comparison of the existing smart grid situations, and also provides insights into the managerial perspective of smart grid. USA, Europe and 
China are selected for the represented areas, which represent a spectrum of diverse political, economic, environmental and technological situations with different smart grid foci.

Despite the widespread impact of cross-national comparison research on smart grid, it is surprising that, existing comprehensive reviews are rather limited, which has resulted in a large body of literature that lacks integration. The proliferation of smart grid research made it necessary for us to develop specific criteria to limit the scope of our review. In addition, the smart grid literature spans diverse disciplines, such as academic papers, government and industry reports. Thus, we limited our focus to articles published in IEEE Xplore and Google scholar database. We extended our review by also searching the references of articles returned in our first search to identify additional articles. We recognize that, many studies use different terms, so we searched for articles that use the term of "smart grid + country/nation/international/America/Europe/China". In cases where a relatively large number of studies share a common theme, we have included a sampling of those that are indicative of the national context of USA, Europe and China. We found 28 articles that met our search criteria, summarized in Table 1 [10-32].

This paper completes a qualitative content analysis in which data (the academic papers) are coded in preparation for comparison and interpretation. First, for the open coding, we have coded all texts inductively in preparation for the identification of relevant text pieces. Second, we complete the selective coding of the text segments identified in the open coding. The software NVivo is applied to code all the text. The main architecture of the analysis is based on the initial open coding where we explored five main themes: technological system, political situation, economic situation, market and cultural impact.

In order to fill the gap of the sidedness of the current cross-national smart grid, research which mainly focuses on the technological aspect. We describe each theme found in the coding and draw conclusions from them. Second, we discuss the missing part in the current cross-national smart grid research, and bring attention to the importance of the international transition of the smart grid solution. Finally, we offer recommendations to build on this body of research.

\section{The Comparison of Current Smart Grid Research in EU, U.S., and China}

The smart grid development is diverse in different countries due to the different situations. Apparently, there are different timeline and focuses. For instance, China officially announced the smart grid plan and development in 2009 by the East China Power Grid Company $[15,16]$. Compared to China, USA has much longer history of smart grid development. The significant efforts in the USA have been dedicated to develop new technologies since 1980s [16] and the U.S. smart grid initiative is the official policy of grid modernization in the U.S. as formalized by the 2007 [19]. These social aspects are described as the social circumstance of the smart grid development and compared between Europe, U.S. and China in the following section.

Most national/cross-national research on the smart grid development focuses on the technological aspect, and the following section will try to figure out the differences and similarities of the smart grid technology development in China, Europe and the U.S., which is described as the construction of smart grid development in this paper and introduced in Section 2.2.

\subsection{The Circumstance of Smart Grid Development}

By summarizing the literature, the circumstance of the smart grid development can be divided into market, economy, policy (including rules, regulations and standardization) and energy resource. These elements decide the direction and focus of a national smart grid initiative and development. For instance, the geographic diversity and economic imbalance drives both Europe and China to focus the transmission and 
Table 1 Overview of the national/cross-national research on smart grid.

\begin{tabular}{|c|c|c|}
\hline Title & Citation & Topic area \\
\hline New challenges to power system planning and operation of smart grid development in China & Ref. [10] & China \\
\hline $\begin{array}{l}\text { The constructive situation and developing direction of the electricity consumption information } \\
\text { collection system in China }\end{array}$ & Ref. [11] & China \\
\hline Long term energy scenario for China & Ref. [12] & China \\
\hline Application of smart power grid in developing countries & Ref. [13] & China, India and Brazil \\
\hline Discussion on smart grid development in China & Ref. [14] & China, USA and Europe \\
\hline Research on smart grid in China & Ref. [15] & China, USA Europe \\
\hline The implication and implementation of smart grid in China & Ref. [16] & USA, EU and China \\
\hline Comparison of the development of smart grids in China and the United Kingdom & Ref. [7] & UK and China \\
\hline A comparison of technology trajectories between the global and the United States in smart grid & Ref. [17] & USA and global \\
\hline $\begin{array}{l}\text { Grid modernization efforts in the USA and Brazil—some common lessons based on the smart } \\
\text { grid initiative }\end{array}$ & Ref. [18] & USA, Brazil \\
\hline A comparison of smart grid technologies and progresses in Europe and the U.S. & Ref. [19] & Europe, USA \\
\hline Creating a smarter U.S. electricity grid & Ref. [20] & USA \\
\hline Analysing demand-side management potential: situation in Europe and the Czech Republic & Ref. [21] & Europe, Czech Republic \\
\hline Electric vehicles in low voltage residential grid: a Danish case study & Ref. [22] & Denmark \\
\hline How do the benefits from active demand vary? A comparison of four EU countries & Ref. [9] & $\begin{array}{l}\text { Europe: Belgium, } \\
\text { Germany, Italy and Spain }\end{array}$ \\
\hline ICT, growth and productivity in the German energy sector — on the way to a smart grid? & Ref. [23] & Germany \\
\hline Integrative energy market as system integrator of decentralized generators & Ref. [24] & Germany \\
\hline $\begin{array}{l}\text { Learning from experiences of the prior Swedish electrical distribution system } \\
\text { regulation-reference material when developing the future regulatory incentives }\end{array}$ & Ref. [25] & Sweden \\
\hline Northern Isles new energy solutions: active network management stability limits & Ref. [26] & Northern Isles \\
\hline Performance results from 100,000+ PRIME smart meters deployment in Spain & Ref. [27] & Spain \\
\hline Real-time market concept architecture for EcoGrid EU—a prototype for European smart grids & Ref. [28] & Europe \\
\hline Smart grid - German and Russian perspectives in comparison & Ref. [8] & Germany and Russia \\
\hline Smart grid technologies in Europe: an overview & Ref. [29] & Europe \\
\hline Smart metering for the future energy systems in the Netherlands & Ref. [30] & Netherlands \\
\hline Towards a Danish power system with $50 \%$ wind — smart grids activities in Denmark & Ref. [31] & Denmark \\
\hline Design of demand response programs in emerging countries & Ref. [32] & $\begin{array}{l}\text { Latin American: Brazil, } \\
\text { Colombia, Chile }\end{array}$ \\
\hline Roles and responsibilities in smart grids: a country comparison & Ref. [6] & $\begin{array}{l}\text { UK, Denmark, France, } \\
\text { USA }\end{array}$ \\
\hline Survey of smart grid concepts, architectures, and technological demonstrations worldwide & Ref. [3] & EU, USA \\
\hline
\end{tabular}

integration of the smart grid development. However, the global pressure, economic growth and society demand make China more concern the strong and reliable, efficient and economical power grid.

\subsubsection{Economy}

The EU vision on smart grid is driven by the long-term objective towards a decarbonised and sustainable economy. Within this vision, the EU electricity system is concerned on introducing low carbon and more renewable sources into the existing grid [16]. For instance, "A visionary Danish energy policy" by the Danish government [33], published in
2007, described the energy development policy towards year 2025. In the report, the government plans to hold the energy saving initiatives must grow $1.25 \%$ annually, and the share of renewable energy to at least $30 \%$ of the total energy consumption by 2025 .

The EU and the U.S. have different approaches in fostering smart grid technology. Europe has been influenced by concerns derived from the diversity and evolution of power grids across European countries, while the U.S. needs to increase security and to respond to the predicted growth in demand for a long-term vision. It is expected that, such technologies will have 
widespread growth subject to economies of scale [19].

With the high speed growth of Chinese economy and electricity demand, There is around 12 percent growth of electricity consumption per annum on average, which has been maintained in over the recent eight years [13]. Therefore, integrated usage of smart grid and renewable energies is an inevitable choice for China to address issues in its power industry and develop a lower-carbon economy, and the government has stated that, it wants to clean up its act by boosting renewable power generation to 15 percent of the total power supply by 2020 [10]. In order to mitigate the trend of global warming, Chinese government speed up the development of renewable energy, such as wind power and solar power [16].

\subsubsection{Policy and Regulation}

The policy definitely influences the national smart grid development, not only for household but also the industrial strategy of smart grid adoption and technology development. The role of regulator and government play different roles between European countries. For instance, the regulator and the government play a strong role in facilitating the discussion in Denmark and UK, such as open standards and discussion platform for all market participants to ensure the establishment of common standards. Comparatively, if there are only few actors dominate the smart grid developments, standards are a minor issue, such as in France [6]. Since energy providers are unable to cope with massive amounts of unpredictable renewable energy sources, many countries and states impose by law specific limits for customer participation in energy generation. For example, this limit is set to $1 \%$ of all customers in Massachusetts [29].

In the U.S., regulators and policy makers are facilitators to coordinate the development and to establish a suitable framework for smart grids [34]. Their roles involve rethinking the principles of regulation, facilitating the emergence of standards and information exchange among stakeholders, educating and involving stakeholders and the public into a smart grid dialogue as well as funding of research, development and demonstration projects [6].

In China, the legislative institutions (e.g., central government and local governments) have an influence on the smart grid development. For instance, the central government announced the FYP (Five Year Plan), the REL (Renewable Energy Law) and the Energy Conservation Law. The central government and the local governments might have different incentives in the smart grid development without homogeneous aims. Therefore, their influence may be diverse and the power structure is unclear so far which leads to several issues (e.g., overlapping authorities, inefficient processes, etc.) [35].

\subsubsection{Energy Resources}

The energy structure strongly influences the national strategy for the development of renewable energy and smart grid. Europe is relatively deficient in traditional fossil energy resources and has high reliance on import. When political conflicts or instabilities arise from time to time, energy supply in Europe could be seriously disturbed [3]. Therefore, Europe specifically focuses on the renewable energy deployment. For instance, Denmark early on focused on a diversified energy mix, promoting renewable and energy efficiency. Consequently, in 2009, the Danish system already exhibited $18.5 \%$ of intermittent renewable generation (mostly wind power) [6]. The renewable energy conditions are different between European countries, such as the main renewable energy in Denmark is wind power, and tidal power in Norway.

The United States has some of the best renewable energy resources in the world, which have the potential to meet a rising and significant share of the nation's energy demand [36]. The growth of generation in the form of new installed capacity in the US is expected to grow by $260 \mathrm{GW}$, and almost $25 \%$ is expected to come from renewable resources; $18 \%$ is projected to use coal and approximately $5 \%$ is projected to use nuclear as the fuel; and almost $53 \%$ of the new additions is expected to use natural gas as a fuel source [18]. Hydroelectric 
power is currently the largest producer of renewable power in the U.S., and The United States is the fourth largest producer of hydroelectricity in the world after China, Canada and Brazil [37]. The capacity of wind power now exceeds $60,000 \mathrm{MW}$ and supplies $4 \%$ of the nation's electricity [38]. Texas, Iowa and California are the leading states at the wind power development [39].

China has vast territory and abundant renewable energy resources. For instance, China is rich in solar energy resources, and the total amount of solar radiation is $3,340-8,400 \mathrm{MJ} / \mathrm{m}^{2}$ per year; and the potential wind resources are about $1.6 \times 109 \mathrm{~kW}$ per year that mainly locate in the northeast region, north region, northwest region and coastal areas and islands [12]. However, China has formed a coal-dominated energy consumption structure so far. In 2005, China primary energy consumption percentage structure, coal accounted for $68.9 \%$, oil accounted for $21.0 \%$, natural gas accounted for $2.9 \%$ and hydropower accounted for $7.2 \%$ [12].

The coal dominated energy structure causes environmental pollution problem, rapid growth in energy consumption development, and the imbalance between the energy resource distribution and the regional economic development require the development of new clean energy and renewable energy [10].

\subsubsection{Market}

The smart grid markets consist of all kinds of commercial agreements between power system participants (such as bilateral contracts, forward markets, real time markets and power exchanges) [3]. Demand-response management is one of the most important elements that may provide paradigm shifts in the normal operation of the electricity market or from government-mandated energy efficiency standards [19]. As a result, the traditional actors are currently facing a change of roles and, for some of them, an increase of competition from new market actors who bring in unconventional approaches and/or experience from other sectors [6]. However, the current design of electricity markets is not sufficient to manage the challenges that the future power systems will face [28].
The liberalization of the electricity markets is needed, in order to decrease prices and increase flexibility [29]. It has also led to the increased interest from the customer side to participate into the electricity business, with the opportunity of choosing their preferred energy provider at every time, according to their needs and economic situation [31]. Meanwhile, the dynamic pricing has enabled economic efficiency, fostered investments in technological innovations, and, for the most part, removed the ills of market power and monopoly [40].

One of the goals of EU smart grid strategy is the electricity market liberalization, with the power market competition and user satisfaction pressure $[14,30]$. The UK energy market is characterized by full liberalization, a strict separation between regulated networks and the competitive supply business, and incentive based regulation [6]. The bulk electricity is traded within the Nordic system via a market system consisting of a day ahead market plus an hourly spot-market that also has the functions of an balancing market [31].

The liberalized European electricity market requires an improved data exchange between all market participants for optimizing the coordination between different national systems [8]. Therefore, the standardization is essential for the EU energy system. However, the biggest obstacle to standardization, and in general to smart grid implementation in Europe, is given by the complex situation of the European energy market, where regulated and liberalized regimes still coexist [29]. For example, The French electricity market is among the most centralized in Europe [6]. Particularly, the issues of standardization become more important in countries with higher degree of decentralization and a more market-orientated approach [6].

Dynamic pricing, which is available in the U.S. bulk power (transmission) markets since mid-1990s following deregulation of the industry [40]. The introduction of smart grid changes the traditional roles 
and responsibilities in the US that a centralized producer-controlled system moves towards less-centralized consumer interactive systems [40]. Meanwhile, standards have gained significant attention, although the DSOs (distribution system operators) traditionally have a strong and central role, but the actors are geographically dispersed throughout the various states in the U.S. [6]. The standardization concern is similar to the situation in Europe.

China will be one of top smart grid market in the world in the coming years [13]. However, China's current energy system cannot meet the smart grid requirement and is unable to support new energy import, execution of ladder price of resident and the promotion of interactive electricity consumption service [12]. Meanwhile, the electricity price was not opened to follow the electricity market, so there is limited development on the demand side management and customer participation [10]. Chinese power industry is facing the uncompleted formed national electricity market [15]. In the future, China energy market price also needs response to the environmental costs to give sufficient encouragement through proper regulations and tax subsidies in the form of change of the type energy [12].

\subsubsection{Stakeholders}

The stakeholders plays different roles with regards to the operation of the smart metering system, and in return the system has diverse effects on the ways these stakeholders interact with the system [30]. For instance, Denmark has a tradition of consumer involvement via municipal and consumer-owned network operators. With its history of bottom-up approaches, the targeted smart grid concept aims to decentralize responsibilities in the system and to equally incorporate demand side and generation resources [6].

The energy sector in France is the traditionally central approach. This central organizational structure drives a strong focus on the role of network operators [6]. The US power industry landscape is marked by vertically integrated electric utilities similar to France, in US, the network operator takes a strong role, while the emergence of new smart grid actors receives little attention [6].

The key stakeholders in China include Chinese government, power grid companies, global equipment and service providers, local equipment and service providers [41]. However, there is a neglected the role of the end consumer, who is obviously highly affected by the smart grid development [35].

2.1.6 Smart Grid Solution (Service or Product)

The product and service with the smart grid concept is important to the energy market. There are two vital elements of the smart grid: smart customer, the set of technologies that enable consumers to observe and control their consumption [42]. For instance, the intelligent and inter-connected interface end devices or other visualisation devices which will make it possible for the end consumers to optimize their power consumption [29], and smart metering can allow utility customers to take advantage of ToU (time-of-use) pricing that was formerly available only to large commercial/industrial users [3].

Europe adopts a strongly user-centric approach for all customers with revolutionary new technologies, products and services [3]. For instance, Finland focuses on customer interaction and service provision through an existing internet connection, i.e., provision of home area network [43].

The acceptance of consumers regarding smart metering and changes in general is a challenge. In some U.S. states, consumers raised concerns to the installation of smart meters, concerned about increase in the electricity bill, or privacy information's being transmitted to the utility [19].

Customers are on the margin of the smart grid in China, although more and more customers require higher service quality, and flexibility of power supply choices [10]. With the improving of future Chinese electrification level, China needs to continuously focus the intelligent electricity consumption include intelligentized electricity consumption service, electricity 
consumption collection system, management and decisionmaking of intelligentized marketing business, intelligentized demand side management and customer resource utilization and development [11].

\subsection{Construction of Smart Grid Development}

It is expected that, smart grid related technologies would have widespread growth subject to economies of scale [19]. According to the 28 articles, the main elements of smart gird construction are: transmission, distribution, ICT, energy storage and operations.

\subsubsection{Transmission}

The conditions of transmission grid are different across European countries. For instance, the UK emphasizes developments within distribution networks including the demand side. Most of the time, the power system operates inefficiently with generation capacity on average utilized below $55 \%$ and transmission capacity below $50 \%$ due to the dimensioning of the UK electricity system for supplying the peak load [21]. Denmark's smart grid focuses on the integration of renewable energy sources, expansion of transmission and distribution networks, active customer participation, advances in information and communication technologies, markets and pioneering concepts of system control and operation in the Danish power system [31].

There are several innovations in the U.S. transmission grid, such as the wide-area measurement and fast controls, and the installation of power system stabilizers, phase shifting transformers, flexible ac transmission system devices, and PMUs (phasor measurement units) [19]. The main drivers are due to the complex situation and the transmission failure experience. The electric grid in the U.S. is composed of approximately 15,000 generators operating in 10,000 power plants, with approximately 160,000 miles of high-voltage transmission lines. There are several failures occurred on the high voltage transmission network, for instance, the 2003 Northeast blackout when 50 million customers suffered power outages that lasted up to a couple [20].

UHV (ultra-high voltage) power grid transmission is the main feature of the Chinese power grid [7]. The power system conditions in different areas of China are very different, and it determines China unique characters of large sending ends, large receiving ends, and large power transmission [10].

\section{Distribution}

Distribution networks will dramatically change in the near future, and energy storage is expected to become increasingly available, even at the distribution level, in order to compensate the intermittent nature of renewable energy sources that will penetrate the distribution sector [19].

Europe focuses on more reliable and safer power supply. The German pilot project eTelligence realized a sustainable energy supply system with a regional energy marketplace as a key element [24]. One of the six EU energy strategy goals is to achieve an energy-efficient Europe by improving buildings, transportation, and distribution grids [19]. The EC (European Commission) has started working towards this vision. Since the launch of FP5, several projects dealing with distributed generation integration and decentralised intelligence in distribution grids have been funded in this perspective [16].

USA has as well a great focus on resolving the structure and the deficits of the current energy system such as reliability issues and prepare the infrastructure for increased share of intermittent renewable power. Traditionally distribution systems served demand customers at the very end of the electricity value chain. This paradigm changed with distribution generation and storage, which increased the importance of information on demand, generation and smart metering [6]. The development of smart grid was designated as a national policy goal, and as of 2011, eight stats adopted deployment plans for advanced metering infrastructure, 12 adopted requirements for utilities to offer dynamic pricing and almost all stats are active or evaluating 
their policy options in net metering, distribution, generation or energy efficiency [6]. About 140 projects have been funded under the program of consumer behavior in response to installations of smart-meters. Several states have adopted regulations that require utilities to install smart meters and make other smart grid investments that both will change and enhance the development within power distribution [20].

China has priority in constructing smart distribution grid [14]. The imbalance in the distribution of energy resources and the development of regional economic requires the high efficient development of energy resource in western region to satisfy the electricity demand of whole country. Besides, the limitation of environmental capacity confines conventional coal-fired thermal power in East China, which requires a new model of power supply, which will carry out large-scale power flows and balance between regions [10]. To be specific, in technical aspects of distribution and supply link, distributed generation and coordinated development of transmission and distribution network [10]. Another challenge for China's power industry development is how to improve customer service on the premise of ensuring the user power supply [14]. In 2008, Shanghai Municipal Electric Power Company launched the research of intelligent distribution network, focusing on smart metering, distribution automation, and user interaction etc. [16].

- ICT (Communication, Demand-Response) and Platform

One of the focuses of the ICT and the demand-response development in Europe is the integration to the whole EU smart grid network. Referring to the EU technology platform smart grid, the concept of the smart grid is defined as an "electricity network which intelligently integrates the actions of generators and consumers connected to it in order to efficiently deliver sustainable, economic and secure electricity supplies" [16]. Another focus is in conjunction with the market understanding and customer demanding. The development in communication technologies will allow small end-consumers and small-scale DER (distributed energy resources) to participate in electricity markets [28, 31]. Some EU research tried to study the active demand and demand-side management, e.g., Refs. [9, 21]. For instance, the real-time market concept architecture for EcoGrid EU provides a market-based platform and ICT infrastructure that extends the current electricity market to a shorter time horizon and to smaller assets [28].

The EU and the U.S. have different approaches in fostering smart grid technology. Europe has been influenced by concerns derived from the diversity and evolution of power grids across European countries, while the U.S. needs to increase security and to respond to the predicted growth in demand for a long-term vision [19]. The US DoE (Department of Energy) characterizes a smart grid as one with the following characteristics: (1) ability to perform self-healing and operate resiliently against cyber and physical attacks; (2) enabling active participation of consumers in demand response [18]. Meanwhile, the major failure occurred on the high voltage transmission network that shows the US poor communications between system operators of interconnected control areas [20] which require more increased digital information and controls and dynamic optimization of grid operations, including cyber security [19].

There is no sufficient research on the smart grid platform in China until now. There are several articles discussing the future grid in China that should improve enterprises information platform construction, investment evaluation system or smart grid comprehensive assessment systems in China [13]. China's smart grid construction need to be based on the specific characteristics of China's power grid: improve power communication network construction [14].

- Energy Storage and Equipment

Smart grid varies throughout Europe because of the differences in the countries energy markets, but a common factor is that, the smart grid is high on the political agenda in all of the countries, especially the 
focus on the increasing amounts of decentralized generation, renewable energies and storage [6]. Technology is the key consideration and it can be defined by certain existing equipment and systems within the smart grid sectors. European Energy Research alliance is therefore working under the objective of integrating energy storage and investigating how to achieve a better integration of flexible demand. Renewable sources are producing a large amount of variable generation, which cannot be forecasted and which can create problems in the electrical network. One of the solutions could be to add energy storage into the system which could be in the form of centralized or distributed energy storage [3].

According to the US DoE, the smart grid characteristics in the US are: incorporating renewable resources and energy storage along with conventional installations [18]. Due to the large scale of the geographical distribution in the U.S., energy storage is expected to become increasingly available, even at the distribution level, in order to compensate the intermittent nature of renewable energy sources that will penetrate the distribution sector [19]. In 2007, EISA07 (Energy Independence and Security Act) formalized the standard development for communication and interoperability of equipment, and the deployment of "smart" technologies and integration of "smart" appliances and consumer devices are also emphasized in the U.S. [19].

It is a tradition for China to emphasize technology development, and in fact, the equipment in China is more advanced than those in developed countries. Thus, smart power grid has a bright prospect in China [14]. Therefore, the challenge and requirements for power system planning and operation in China is the energy storage and other new technologies widely used in power system [10], enhancing the ultra-high voltage main power grid and its supporting equipment construction [14].

\section{- Operations}

The Energy Independence and Security Act of 2007 defines the term "smart grid" as a modernization of the electricity delivery system so it monitors, protects and automatically optimizes the operation of its interconnected elements [16]. The operations of smart grid generally includes automation, digitalization, controllability, optimization, security, forecasting. Control and operation of the traditional power system used to be successful and less complicated, though such a system is environmentally polluting, and unable to fulfill the increased needs from the market and customer [31]. The traditional grid development through "centralized" approach is reaching its limits and alternative and complementary approaches are needed. This can be achieved through introducing more decentralised mechanisms and more intelligent approaches at all level of planning, operation and control of the power grid [16].

The motivation behind the focus of operation efficiency improvement differs across European countries. However, in general, there are some common drivers that encourage the different governments to develop the operation efficiency within their respective countries. Facing the power market competition and user satisfaction pressure, European power enterprises and government have focused on improving operation efficiency, reducing electricity prices and strengthening interaction with the customers [14]. Each one of these stakeholders plays a different role with regards to the operation of the smart metering system, and in return the system has diverse effects on the ways these stakeholders interact with the system [30]. The highest levels of safety and security of supply become one of the concerns derived from the diversity and evolution of power grids across European countries [16].

One of the US smart grid characteristics is: dynamic optimization of grid operations, including cyber security (optimizing assets for efficient operation) $[18,19]$. In the U.S., there were several large power outages in recent years. Therefore, electric power industry pays closer attention to power quality and reliability, customers draw out more requests for electricity supply. 
The ever-increasing demands of national security and environmental protection policy of the United States [15]. Similar to China, that the technology of security monitoring is one of the new challenge and requirement for the smart grid operation in China [10].

\section{- Discussions}

According to the literature analysis, this paper identified eleven elements (six elements in the social aspect and five elements in the technological aspect) that have been popularly discussed in the comparative/national smart grid studies. Although the technological aspect has been discussed in many papers, this paper still tried to discuss both social and technological aspects with a new form to present an integral picture. Some articles have mentioned and primarily discussed few social elements, such as Fang, et al. [44]. However, some important social elements are still missing. For instance, the framework [44] misses the political, economic and market elements.

Majority of current research focuses on the "comparison" between countries. Meanwhile, there is limited research present the similarity and dissimilarity of smart grid development across countries. This paper argues that, the similarity and dissimilarity is important for the smart grid technology and knowledge transfer across countries. Also, the across-national collaboration is the only solution for the global energy issues. The first step for the across-national smart grid collaboration is the similarity/dissimilarity understanding, and then it may explore the collaboration possibility and focus area. Tables 2 and 3 show the example of element comparison between Europe, the U.S. and China.

Table 2 Social aspect comparison across Europe, the U.S., and China.

\begin{tabular}{|c|c|c|c|c|}
\hline \multicolumn{3}{|r|}{ Europe } & U.S. & China \\
\hline \multirow{6}{*}{ 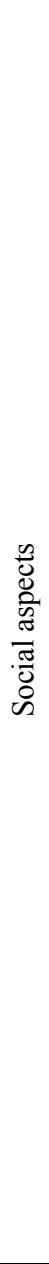 } & $\underset{\Xi}{\overparen{\Xi}}$ & $\begin{array}{l}\text { Long-term } \\
\text { Low carbon economy } \\
\text { Sustainable economy (renewable source) } \\
\text { energy saving }\end{array}$ & $\begin{array}{l}\text { Long-term } \\
\text { Security technology demand growth }\end{array}$ & $\begin{array}{l}\text { Economy high speed growth } \\
\text { Electricity demand } \\
\text { Low carbone conomy } \\
\text { Global warming-renewable power }\end{array}$ \\
\hline & 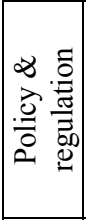 & $\begin{array}{l}\text { Discussion facilitation } \\
\text { Common standard establishment } \\
\text { Diversity across countries }\end{array}$ & $\begin{array}{l}\text { Framework and principle of smart grid } \\
\text { development } \\
\text { Emergence of standards and } \\
\text { information exchange } \\
\text { Stakeholders' education and } \\
\text { involvement research support }\end{array}$ & $\begin{array}{l}\text { Central government-related national } \\
\text { plan, law, and incentives } \\
\text { Local government: incentives } \\
\text { Overlapping authorities and unclear } \\
\text { power structure }\end{array}$ \\
\hline & 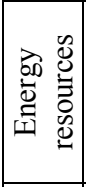 & $\begin{array}{l}\text { Traditional fossil energy } \\
\text { High import reliance } \\
\text { Diversified energy mix } \\
\text { Different renewable energy conditions }\end{array}$ & $\begin{array}{l}\text { Large production of hydro electric power } \\
\text { Large capacity of wind power } \\
\text { Expected power generation: } 25 \% \text { is } \\
\text { renewable resources, } 18 \% \text { is coal, } 53 \% \\
\text { is natural gas }\end{array}$ & $\begin{array}{l}\text { Abundant renewable energy } \\
\text { resources, e.g., solar and wind power } \\
\text { Coal-dominated energy consumption } \\
\text { structure }(68.9 \% \text { coal, } 21 \% \text { oil })\end{array}$ \\
\hline & 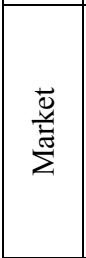 & $\begin{array}{l}\text { Regulated and liberalized regime sco exist } \\
\text { Complex situation across European energy } \\
\text { markets } \\
\text { High demand of data exchange and } \\
\text { standardization } \\
\text { Power market completion } \\
\text { User satisfaction pressure }\end{array}$ & $\begin{array}{l}\text { Dynamic pricing in the bulk power } \\
\text { market } \\
\text { Industry deregulation } \\
\text { Moving towards less-centralized } \\
\text { consumer interactive systems } \\
\text { Standardization concern }\end{array}$ & $\begin{array}{l}\text { Uncompleted formed national } \\
\text { electricity market } \\
\text { Unopened electricity price } \\
\text { Limited demand side management } \\
\text { Limited customer participation } \\
\text { Future environmental cost addition }\end{array}$ \\
\hline & 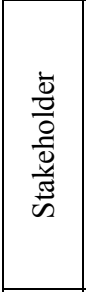 & $\begin{array}{l}\text { In liberalized energy countries: } \\
\text { Bottom-up approach } \\
\text { Consumer involvement } \\
\text { Decentralized responsibilities } \\
\text { Municipal and consumer-owned network } \\
\text { operators } \\
\text { In centralized energy countries: } \\
\text { Strong role of network operators } \\
\end{array}$ & $\begin{array}{l}\text { Vertically integrated electric utilities } \\
\text { Strong role of network operator } \\
\text { Little attention on new smart grid actors }\end{array}$ & $\begin{array}{l}\text { Key stakeholders: Chinese } \\
\text { government, power grid companies, } \\
\text { global/local equipment \& service } \\
\text { providers } \\
\text { Neglected role of end consumers }\end{array}$ \\
\hline & 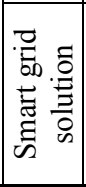 & $\begin{array}{l}\text { User-central technologies, product and } \\
\text { service, e.g., smart metering } \\
\text { Customer interaction } \\
\text { Internet connection }\end{array}$ & $\begin{array}{l}\text { Challenges of smart meter in stallation } \\
\text { due to electricity bill in crease and } \\
\text { information privacy }\end{array}$ & $\begin{array}{l}\text { Customers' demand on: higher } \\
\text { service quality, flexibility of power } \\
\text { supply choices } \\
\text { Lack of intelligent electricity } \\
\text { consumption }\end{array}$ \\
\hline
\end{tabular}


Table 3 Technological aspect comparison across Europe, the U.S., and China.

\begin{tabular}{|c|c|c|c|c|}
\hline & & Europe & U.S. & China \\
\hline \multirow{5}{*}{ 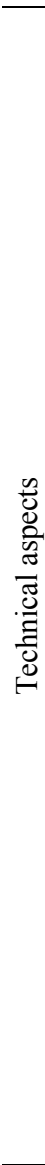 } & 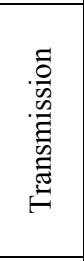 & $\begin{array}{l}\text { Distribution network including the } \\
\text { demandside } \\
\text { Integration of renewable energy resource } \\
\text { Expansion of transmission and distribution } \\
\text { network } \\
\text { Pioneering concepts of system control and } \\
\text { operation }\end{array}$ & $\begin{array}{l}\text { Complex situation } \\
\text { Transmission failure experience } \\
\text { wide-area measurement and fast control } \\
\text { Several types of device installation }\end{array}$ & $\begin{array}{l}\text { Ultra-high voltage power grid } \\
\text { transmission } \\
\text { Various power system condition in } \\
\text { different areas }\end{array}$ \\
\hline & 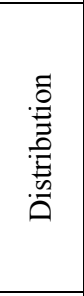 & $\begin{array}{l}\text { "Energy-efficient Europe" } \\
\text { Reliable, safer, and sustainable energy } \\
\text { supply system } \\
\text { Distributed generation integration } \\
\text { Decentralized intelligence in distribution } \\
\text { grid }\end{array}$ & $\begin{array}{l}\text { Preparing the infrastructure for } \\
\text { intermittent renewable power } \\
\text { Smart grid as a national policy goal } \\
\text { Dynamic pricing, net metering, } \\
\text { distribution, generation and energy } \\
\text { efficiency }\end{array}$ & $\begin{array}{l}\text { Priority in constructing smart } \\
\text { distribution grid } \\
\text { Imbalance in the energy resource } \\
\text { distribution } \\
\text { Large-scale power flows required } \\
\text { Efficiency of energy resource in } \\
\text { western region required } \\
\text { Technical aspect focus } \\
\end{array}$ \\
\hline & 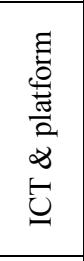 & $\begin{array}{l}\text { Integration to whole EU smart grid } \\
\text { network } \\
\text { Conjunction with market understanding, } \\
\text { and customer demand } \\
\text { Communication technologies } \\
\text { Demand response management } \\
\text { Market-based platform }\end{array}$ & $\begin{array}{l}\text { Security concern } \\
\text { Poor communication } \\
\text { Responsiveness to predicted growth } \\
\text { and demand required } \\
\text { Digitalization required }\end{array}$ & $\begin{array}{l}\text { Lack of construction and related } \\
\text { technology }\end{array}$ \\
\hline & 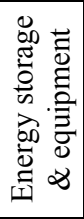 & $\begin{array}{l}\text { Differences in the Europeans markets } \\
\text { Shard political objective regarding smart } \\
\text { grid } \\
\text { European energy research alliance } \\
\text { Centralized or distributed energy storage }\end{array}$ & $\begin{array}{l}\text { Energy storage at distribution level } \\
\text { Incorporation of renewable resources } \\
\text { and energy resource } \\
\text { Standardization of equipment } \\
\text { interoperability } \\
\text { Smart consumer devices emphasized }\end{array}$ & $\begin{array}{l}\text { Advanced equipment and technology } \\
\text { Challenge in energy storage and other } \\
\text { technologies widely used } \\
\text { Supporting equipment construction } \\
\text { required }\end{array}$ \\
\hline & 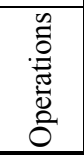 & $\begin{array}{l}\text { Operation efficiency improvement } \\
\text { Customer interaction } \\
\text { Electricity price reduction } \\
\text { Various stakeholders' roles }\end{array}$ & $\begin{array}{l}\text { Dynamic optimization of grid } \\
\text { operations } \\
\text { Power quality, reliability, and security } \\
\text { Environmental protection policy }\end{array}$ & Security monitoring technology \\
\hline
\end{tabular}

Taking the market element for example, both Europe and the U.S. concern the standardization, but not in China. There are several reasons behind, and it also indicates collaboration opportunity regarding standardization, such as experience transfer from Europe to China.

This paper found that, some elements are missing in the current smart grid comparison studies, which are important for the international smart grid collaboration. These elements can be defined as: demographic, geographic and cultural elements (shown in Fig. 1). For instance, the geographic situation of economics and energy resources influences the policies or national strategies for the smart grid development. China has high interest and focus on the ultra-high voltage power grid transmission due to the unbalanced energy resources and economic development.

This paper argues that, it is important to have a big picture of the smart grid development across countries. The scale and focus of the national smart grid should be presented under the global smart grid structure. It is no doubt that, the worldwide smart grid direction is transforming the traditional energy system to the entirely smart energy system, and Fig. 2 shows the smart grid dimension with the national scale and focus. Taking the stakeholder dimension as example, there should be a fully active stakeholder participation to support the entire smart energy system. At this dimension, Denmark is more advanced than the U.S. and China.

\section{Conclusions and Further Research Suggestions}

- Systematic Research on Cross-National Smart Management System

The current cross-national smart grid research has 


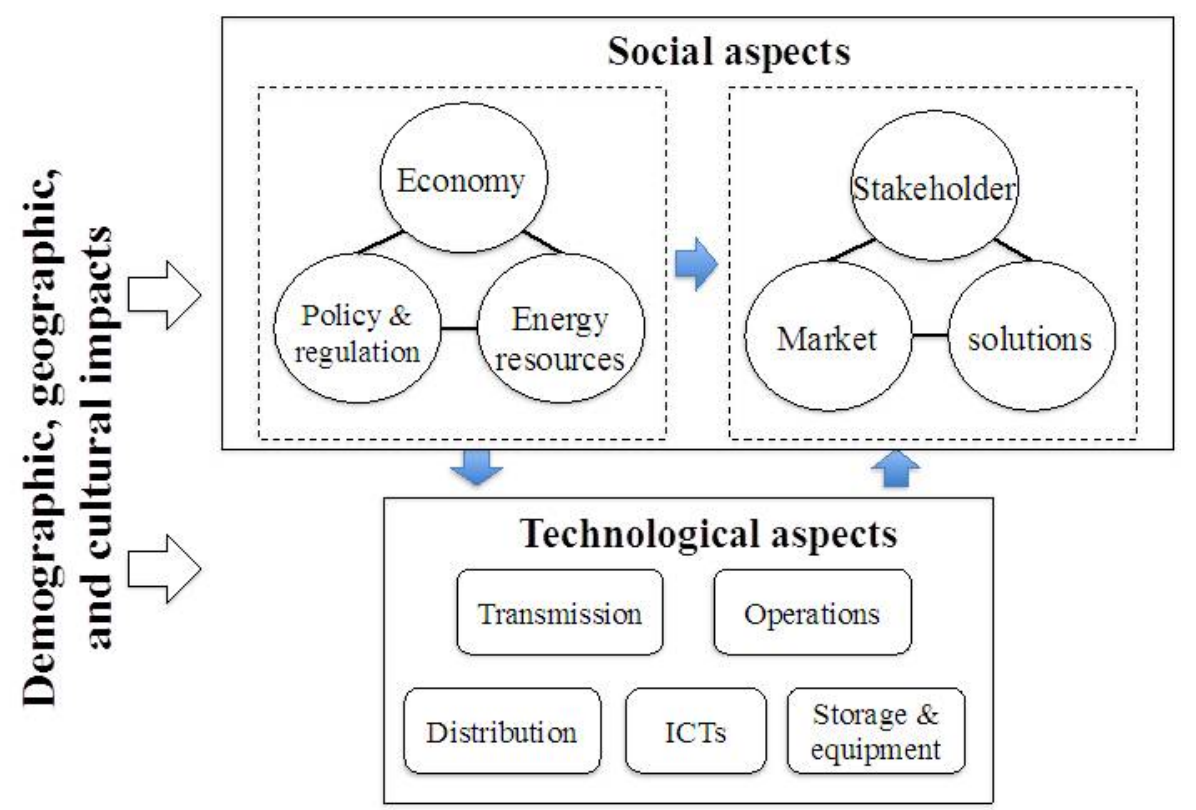

Fig. 1 The common elements in the smart grid comparison studies.

\section{Worldwide smart grid direction}

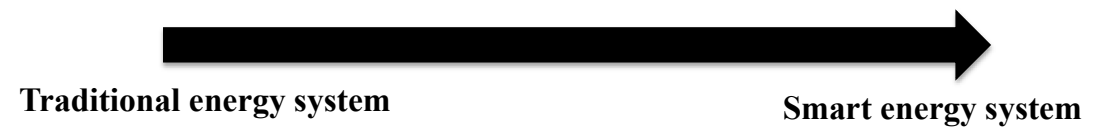

Economy

Policy \& regulation

Energy resources

Market

The U.S.

$\stackrel{\text { Denmark }}{\longrightarrow}$

Stakeholder

Smart grid solution

Transmission

Distribution

Smart grid scale and

ICT \& platform

Storage \& equipment

Operations

Fig. 2 Global- national smart grid scale and focus.

not provide a systematic, overall view with the whole picture integrating social and technological aspects. Therefore, a tool or database is recommended for the future research. Meanwhile, a template is recommended for the systematic comparative studies.

- The Global-Local Smart Grid Solution

Current research mainly focuses on the cross-national comparison or international collaboration. Our research findings show that, there are similarities and differences across national smart grid environment and development. Therefore, it is necessary to integrate global and local aspects for the further smart grid solution.

- More Multidisciplinary Research (Market, Economic, Politics, Management)

Some articles have done the studies on the social aspect, however there is no through research, either no sufficient on the cross-national concern. Meanwhile, due to the limited knowledge of each discipline, it is necessary for researchers in different 
disciplines to collaborate.

- Correlation between Different Systems and Aspects

This research found out that, the social factors impact on the technological development of smart grid. Fig. 1 shows the correlations. Meanwhile, the research also found that, the correlations might be different across countries. Therefore, the further research is recommended to explore it.

- Cultural Impact

In the comparison, this research realized that, the focuses of smart grid development are different even inside Europe. The social responsibility and ethical principle of governments and citizens influence the smart grid development. For instance, Denmark plans to have $100 \%$ renewable energy in 2050 , and the high electricity price (including tax and research and development) is more acceptable for households in Denmark. Therefore, more research is expected to explore the cultural impact to the global smart grid development.

\section{References}

[1] Jirapornanan, A. 2010. Study of Smart Grid for Thailand and Identification of the Required Research and Development. New York: IEEE.

[2] Sebitosi, A. B., and Okou, R. 2010. "Re-thinking the Power Transmission Model for Sub-Saharan Africa." Energy Policy 38 (3): 1448-54.

[3] Hashmi, M., Hanninen, S., and Maki, K. 2011. "Survey of Smart Grid Concepts, Architectures, and Technological Demonstrations Worldwide." In Proceedings of the 2011 IEEE PES Conference on Innovative Smart Grid Technologies (ISGT Latin America), 1-7.

[4] Mah, D. N. Y., van der Vleuten, J. M., Hills, P., and Tao, J. 2012. "Consumer Perceptions of Smart Grid Development: Results of a Hong Kong Survey and Policy Implications." Energy Policy 49 (October): 204-16.

[5] Wojszczyk, B. 2012. "Deployment of Advanced Smart Grid Solutions-Global Examples and Lessons Learned." In Proceedings of the 2012 IEEE PES Innovative Smart Grid Technologies, 1.

[6] Brandstatt, C., Friedrichsen, N., Meyer, R., and Palovic, M. 2012. "Roles and Responsibilities in Smart Grids: A Country Comparison." In Proceedings of the 9th International Conference on the European Energy Market
(EEM), 1-8.

[7] Qiang, S., Jianzhong, W., Yibin, Z., Jenkins, N., and Ekanayake, J. 2010. "Comparison of the Development of Smart Grids in China and the United Kingdom." In Proceedings of the IEEE PES Conference on Innovative Smart Grid Technologies Europe, 1-6.

[8] Moskalenko, N., Styczynski, Z. A., Sokolnikova, T., and Voropai, N. 2010. "Smart Grid- German and Russian Perspectives in Comparison." In Proceedings of the International Modern Electric Power Systems, 1-7.

[9] Cronenberg, A., Delnooz, A., Linke, C., Baron, M., Lago, O., and Linares, P. 2012. "How do the Benefits from Active Demand Vary? A Comparison of Four EU Countries." In Proceedings of the 2012 IEEE International Energy Conference and Exhibition (ENERGYCON), 693-700.

[10] Zhang, R., Du, Y., and Liu, Y. 2010. "New Challenges to Power System Planning and Operation of Smart Grid Development in China." In Proceedings of the 2010 International Conference on Power System Technology, $1-8$.

[11] Jie, L., Qi, C., and Shenchun, Y. 2012. "The Constructive Situation and Developing Direction of the Electricity Consumption Information Collection System in China." In Proceedings of the 2012 China International Conference on Electricity Distribution (CICED), 1-8.

[12] Haochi, G., Mingming, Z., and Lo, K. L. 2010. "Long Term Energy Scenario for China." In Proceedings of the Asia-Pacific Power and Energy Engineering Conference (APPEEC), 1-7.

[13] Nejad, M. F., Saberian, A., Hizam, H., Mohd Radzi, M. A., and Ab Kadir, M. Z. A. 2013 "Application of Smart Power Grid in Developing Countries." In Proceedings of the 2013 IEEE 7th International Power Engineering and Optimization Conference (PEOCO), 427-31.

[14] Siming, L., Yunhui, C., Jing, H., Yongding, F., Bangfeng, L., Hui, H., Jianzhong, Z., and Yongchuan, Z. 2011. "Discussion on Smart Grid Development in China." In Proceedings of the Asia-Pacific Power and Energy Engineering Conference, 1-4.

[15] Jingjing, L., Da, X., and Qian, A. 2009. "Research on Smart Grid in China." In Proceedings of the Transmission \& Distribution Conference \& Exposition: Asia and Pacific, 1-4.

[16] Tianshu, B., Sumei, L., Zhenyu, H., and Hadjsaid, N. 2010. "The Implication and Implementation of Smart Grid in China." In Proceedings of the 2010 IEEE Power and Energy Society General Meeting, 1-5.

[17] Siou-Zih, L., Ssu-Han, C., Chun-Chieh, W., and Dar-Zen, C. 2011. "A Comparison of Technology Trajectories between the Global and the United States in Smart Grid." In Proceedings of the IEEE International Conference on Engineering and Engineering Management (IEEM), 
1028-32.

[18] Suryanarayanan, S., Ribeiro, P. F., and Simoes, M. G. 2010. "Grid Modernization Efforts in the USA and Brazil-Some Common Lessons Based on the Smart Grid Initiative." In Proceedings of the 2010 IEEE Power \& Energy Society (PES) General Meeting, 1-5.

[19] Simoes, M. G., Roche, R., Kyriakides, E., Suryanarayanan, S., Blunier, B., McBee, K. D., Nguyen, P. H., Ribeiro, P. F., and Miraoui, A. 2012. "A Comparison of Smart Grid Technologies and Progresses in Europe and the U.S." IEEE Transactions on Industry Applications 48 (4): 1154-62.

[20] Joskow, P. 2012. "Creating a Smarter U.S. Electricity Grid." Journal of Economic Perspectives 26 (1): 29-48.

[21] Malik, O., and Havel, P. 2011. "Analysing Demand-Side Management Potential: Situation in Europe and the Czech Republic." In Proceedings of the 10th International Conference on Environment and Electrical Engineering, 1-4.

[22] Pillai, J. R., Shaojun, H., Thogersen, P., Moller, J., and Bak-Jensen, B. 2012. "Electric Vehicles in Low Voltage Residential Grid: A Danish Case Study." In Proceedings of the 2012 3rd IEEE PES International Conference and Exhibition on Innovative Smart Grid Technologies (ISGT Europe), 1-7.

[23] Wissner, M. 2011. "ICT, Growth and Productivity in the German Energy Sector-On the Way to a Smart Grid?" Utilities Policy 19 (1): 14-9.

[24] Hollinger, R., and Erge, T. 2012. "Integrative Energy Market as System Integrator of Decentralized Generators." In Proceedings of the 2012 9th International Conference on the European Energy Market (EEM), 1-6.

[25] Wallnerstrom, C. J., and Bertling, L. 2010. "Learning from Experiences of the Prior Swedish Electrical Distribution System Regulation-Reference Material When Developing the future Regulatory Incentives." In Proceedings of the 2010 IEEE PES Innovative Smart Grid Technologies Conference Europe (ISGT Europe), 1-8.

[26] Dolan, M. J., Ault, G. W., Frame, D. F., Gill, S., Kockar, I., Anaya-Lara, O., Galloway, S., O’Neill, B., Foote, C., and Svalovs, A. 2012. "Northern Isles New Energy Solutions: Active Network Management Stability Limits." In Proceedings of the 20123 rd IEEE PES International Conference and Exhibition on Innovative Smart Grid Technologies (ISGT Europe), 1-9.

[27] Sendin, A., Berganza, I., Arzuaga, A., Pulkkand, A., and II Han, K. 2012. "Performance Results from 100,000+ PRIME Smart Meters Deployment in Spain" In Proceedings of the 2012 IEEE Third International Conference on Smart Grid Communications (SmartGridComm), 145-50.

[28] Ding, Y., Pineda, S., Nyeng, P., Ostergaard, J., Larsen, E. M., and $\mathrm{Wu}, \mathrm{Q}$. 2013. "Real-Time Market Concept
Architecture for EcoGrid EU-A Prototype for European Smart Grids." IEEE Transactions on Smart Grid PP (99): $1-11$.

[29] Ardito, L., Procaccianti, G., Menga, G., and Morisio, M. 2013. "Smart Grid Technologies in Europe: An Overview." Energies 6 (1): 251-81.

[30] AlAbdulkarim, L. O., and Lukszo, Z. 2009. "Smart Metering for the Future Energy Systems in the Netherlands." In Proceedings of the Fourth International Conference on Critical Infrastructures, 1-7.

[31] Zhao, X., Gordon, M., Lind, M., and Ostergaard, J. 2009. "Towards a Danish Power System with 50\% Wind-Smart Grids Activities in Denmark." In Proceedings of the IEEE Power \& Energy Society General Meeting, 1-8.

[32] Martinez, V. J., and Rudnick, H. 2012. "Design of Demand Response Programs in Emerging Countries." In Proceedings of the 2012 IEEE International Conference Power System Technology (POWERCON), 1-6.

[33] Danish Energy Authority. 2007. "A Visionary Danish Energy Policy." Danish Energy Authority.

[34] U. S. D. o. Energy (U.S. Department of Energy). 2009. "The Smart Grid: An Introduction." U. S. D. o. Energy. Accessed March 14, 2015. http://energy.gov/sites/prod/files/oeprod/DocumentsandM edia/DOE_SG_Book_Single_Pages\%281\%29.pdf.

[35] Sommer, S., Ma, Z., and Jørgensen, B. N. 2014. "Smart Grid in China-The Key Stakeholders, Policies, Regulations and Challenges." In Proceedings of the 2014 International Conference on Civil, Urban and Environmental Engineering, 1-10.

[36] Institute, W. (The Worldwatch Institute). 2013. "Renewables Becoming Cost-Competitive with Fossil Fuels in the U.S.” Institute, W. Accessed August 18, 2014. http://www.worldwatch.org/node/4526.

[37] U. S. E. I. Administration (U.S. Energy Information Administration). 2011. "Direct Federal Financial Interventions and Subsidies in Energy in Fiscal Year 2010." U. S. E. I. Administration. Accessed August 18, 2014. http://www.eia.gov/analysis/requests/subsidy/.

[38] A. W. E. A. (American Wind Energy Association). 2014. “AWEA 4th Quarter 2013 Public Market Report.” A. W. E. A. Accessed August 18, 2014. http://www.awea.org/4q2013.

[39] A. W. E. Association (American Wind Energy Association). 2007. "Annual U.S. Wind Power Rankings Track Industry's Rapid Growth.” A. W. E. Association. Accessed August 18, 2014. http://www.electricnet.com/doc/annual-us-wind-power-ra nkings-track-industrys-0001.

[40] Kirschen, D., and Strbac, G. 2004. Fundamentals of Power Systems Economics. Chichester, U.K.: Wiley.

[41] Wu, J. D., and Wu, J. I. 2012. "The Smart Grid in 
China-A Discussion Paper.” Energy Transition Research Institute, Annapolis, Maryland, USA.

[42] Tabors, R., Parker, G., and Caramanis, M. 2010. "Development of the Smart Grid: Missing Elements in the Policy Process." Presented at the 2010 43rd Hawaii International Conference on System Sciences (HICSS), Koloa, Kauai, HI, USA.
[43] Hierzinger, R., Albu, M., Elburg, H. v., Scott, A. J., Łazicki, A., and Penttinen, L. 2013. European Smart Metering Landscape Report 2012. Final report, 199. Accessed March 14, 2015. http://www.smartregions.net.

[44] Fang, X., Misra, S., Xue, G., and Yang, D. 2012. "Smart Grid-The New and Improved Power Grid: A Survey." IEEE Communications Surveys \& Tutorials 14 (4): 944-80. 